\title{
Diverse Approaches to Multicultural Art Education: Some Policy Considerations
}

\section{Liam James}

Botfed Research Soceity

Email: jamesl@botfed.com

\begin{abstract}
This article summarizes the extensive controversy that has raged around multicultural art education since its start little over a decade ago. Numerous definitions of multicultural art education are discussed, as well as several assessments of the degree to which minority art and culture should be included. incorporated into and distinct from dominant culture; and, ultimately, rival concepts. On the importance of political involvement and aesthetics in multicultural art education detachment. Throughout the process, certain recommendations for future policy choices are made.
\end{abstract}

\section{Introduction}

To properly understand multicultural art education, we must take a step back and analyze why we provide art education in the first place. To begin, we must acknowledge that all schooling involves an element of custom and inertia; we do things the way we have always done them (or as far back as we can collectively recall), not because they are rational. This is not always or wholly incorrect; what has worked in the past almost certainly has some worth. Nonetheless, it is always beneficial to take a long, hard, critical look at what we are attempting to do from time to time (and whether we are succeeding) ${ }^{12}$.

Art education practice is partially an attempt to provide students with an outlet for their creativity, to allow them to develop their abilities in sketching, painting, and so on. This is the "practical" aspect of art instruction. However, we are also attempting to educate children and adolescents about the art world, which includes knowledge of artists, forms of art, and the history of art, among other things. This is the more 
"theoretical" aspect of art education - the type of thing that proponents of discipline-based art education urge (DBAE).

However, why would one participate in the latter? What are we attempting to achieve with art education's more theoretical component? We do this in part to promote "liberal arts" - the belief that educated appreciation and taste "liberate" a person, allowing them to appreciate paintings, music, theater, and so on more completely and thereby enriching their lives. This is an ancient but still valid rationale, and one that we would consider to be the more "private" aspect of art enjoyment ${ }^{3456}$. However, we aim to assist young people in assimilation to their own culture, which is the more "public" aspect of art education. This is why students in Korea will study more about Korean art history than they will about, say, North African art history. Today, tremendous effort is being made in China to promote Chinese aesthetic education as a method of fostering a feeling of national cohesion.

Which leads us to the topic of why multicultural art education is necessary. Because our (North American) society is multicultural, it cannot be reduced to limited religious, ethnic, or racial categories (in the sense in which the virtually monolithic cultures of Japan or Kuwait, e.g., very nearly can). And there are two reasons for this: The first reason is because our culture is the result of several ethnic groups arriving in North America over several centuries, and the second reason is that our globe is decreasing owing to the spectacular "shrinking world" phenomena. Every kid should have a basic understanding of modern Arabic, Japanese, Chinese, and African cultures as components of the globe with which they, as Americans, must engage. Even if we did not have millions of Islamic students in our American classrooms, the events of September 11 demonstrate our urgent need to learn more about and educate our kids about Islam. While this encompasses more than art education, it does include art, and art is an excellent place to start with young children 7891011 .

And that cultural building (from British to European) continues to constitute the largest proportion of America's cultural roots - not only in terms of population, but also in terms of contribution to American culture. That would be a grave error to overlook. However, since this is not the whole of American cultural history, the assimilation and integration processes must continue. To be more precise, the study of European art and culture must now be supplemented with the study of non-European art and culture that have made substantial contributions to North American culture-Native American, African, Hispanic, Chinese, Indian, Jewish, and Arabic. Africa's influence to American culture is undeniable and enormous. Integration of numerous Native American ancestors, early Chinese immigrants, and later Vietnamese, Japanese, Korean ${ }^{12}$, and Indian, not to mention millions of immigrants from other Islamic nations, has been less apparent. 
There are currently more Muslims in the United States than Jews, and if this comes as a surprise, it is only because Muslims have not yet integrated as well as Jews have. Most non-Jewish schoolchildren, for example, will have some knowledge of Chanukah; nevertheless, the majority will either be unaware of Ramadan or believe it is only observed in nations outside the United States. Today, although many Americans get comfort from their alleged racial origins, race as a scientific notion continues to wane as an increasing number of Americans identify as "Mixed." Thus, the effort of further cultural integration outside the mostly white European American culture must continue 11131415.

\section{Multiculturalism as Diversification, Inclusivity, and an Aesthetics of Relationship}

After more than a decade of multicultural art education, the moment has come to critically examine what multicultural art education has evolved into. To begin, it is unclear what "multicultural art education" entails; a survey of current literature indicates that this umbrella term encompasses a variety of fairly disparate aims. However, that seemingly harmless initial step quickly brings vexing theoretical issues about why European art has been favoured for centuries, including the presumption of the superiority of European art's art critical criteria (and why high European art is considered better than European folk art). Otherwise, it's difficult to justify expanding our art curriculum to include substandard work. We have a solid standard that has been utilized to create a canon of the world's greatest work. John A. Stinespring's (1996) article "Moving from First-stage to Second-stage Multiculturalism in the Art Classroom" demonstrates the critical nature of this change in focus ${ }^{16}$. The first step is simply to include a large number of previously excluded non-European artworks and art traditions (and excluding some from the European canon to make room for the new additions).

Thus, we arrive at the second purpose shared by the majority of multiculturalists: establishing a variety of non-European art on an equal footing with European art. However, if this is the case, we cannot escape the problematic theoretical issue of whether there are multicultural art critical criteria for discriminating between excellent and mediocre art, as opposed to a single universal set of standards that favors European art. If we are serious about presenting varied works of art from multiple cultures as having equal aesthetic value, we may have to adopt a relativized idea of creative excellence-different works of art from diverse civilizations being equally valued for unique cultural reasons ${ }^{17}$.

Clearly, if we are to promote both variety and the concept of relative equality, we must be more receptive to a range of creative excellence criteria. A similar argument is made by K. A. Hamblen (1991). Paulette Spruill-Flemming (1990, 1991) and Graeme Sullivan (1993) both emphasize the importance of moving away from the Eurocentric notion of valuing artworks solely on the basis of autonomous aesthetic standards 
(art for the sake of art, aesthetically detached or disassociated from other, nonaesthetic everyday considerations - the romantic notion of the isolated artist struggling outside of and frequently in opposition to larger society). Rather than that, they argue, we must begin to view art in its broader sociopoliticaleconomic context, not just by including a few non-European works, but by viewing all art in this broader social context, in which all art, including non-European works, will be judged on the basis of its role in the larger social context. As Delacruz (1995) puts it, "multicultural art education involves a rethinking of the nature of art and our relationship with it" (p. 59) ${ }^{18}$.

On the other side, I have come under fire throughout the years for advocating for a broader cultural change. I do believe that there has been an evolution from Old Stone Age hunting and gathering to New Stone Age agriculture to Bronze and Iron Age large-scale literary societies to industrialized and contemporary cultures. However, I do not see contemporary culture as solely Western, despite the fact that most of it originated there (see Japan), any more than I regard Bronze and Iron Age civilization as exclusively Middle Eastern in origin. Regardless of their origins, global cultural movements eventually become multicultural and multinational. While this may be a delicate balancing act, I believe it is a mistake to first identify all Modernism with European culture; and second, to either denigrate European culture as the source of Modernism's worst aspects or to extol the superiority of European culture for Modernism's more positive aspects.

Additionally, it is a fallacy to conceive of all Western aesthetics as the formalist, New Criticism, art for art's sake kind that postmodern critics decry for their lack of social context significance. For at least a century, Western aesthetics has been preoccupied with themes of social and political participation. We must constantly remind ourselves that Marxist and neo-Marxist aesthetics are neither anti-Western or nonWestern, but rather a component of Western aesthetics ${ }^{19}$. Within Western aesthetics, the exact degree of aesthetic autonomy and social importance is a point of contention. When we expose students to any kind of art, we should attempt to situate it within its social and historical context; this is no less true of Greek temple art than of Mayan ceremonial art. Nor should we believe that art serving a nonaesthetic, utilitarian purpose cannot equally serve an aesthetic one. This has also been a long-standing point of contention among Western aesthetics. Otherwise, according to the most limited, purist formalist (New Criticism, art for the sake of art) definition of "fine art" would eliminate Greek, Roman, medieval Christian, and indeed all premodern Western art (beginning roughly in the 16th century). Likewise, it is only through ignorance of nonWestern aesthetic traditions that we presume there is no aesthetic tradition (of a relatively detached enjoyment of art for the sake of art) in some eras of China and India 20.21222324 
If the preceding part is correct, various problems emerge. To begin, why hasn't this been done before; and second, why is it being rejected so strenuously in certain quarters today? This prompts many observers to take a bold political and ideological position, claiming that ignoring or dismissing non-European art is part of Europe's greater neocolonial objective of dominating non-Europeans. This is the neo-Marxist (or neoneo-Marxist) concept that worldwide economic interests have the aim of exploiting and oppressing not just developing nations, but also the poor and disadvantaged inside their own countries. This is multicultural education's anti-Western slant. Against times, multiculturalism seems to be a kind of self-hatred directed at European culture, including art, as if all the world's brutality, greed, and selfishness originated there and should now be vanquished or at the very least ignored. Regardless matter how often this geopolitical perspective is accepted and taken for granted in conversations about multicultural art education, it should be thoroughly questioned. Given the tendency for Western culture to be identified with modern world culture, it is unquestionably a mistake to instill in our children a blanket hatred and rejection of Modernism in all its manifestations (from human rights and democracy to individualism and freedom), an ideal to which the rest of the world aspires. Our approach must be more balanced, emphasizing both good (democratic) and negative characteristics (the legacy of slavery, colonialism, and other forms of economic exploitation).

\section{Multiculturalism as western hegemony}

This brings up another touchy subject. Numerous minority express a desire to remain distinct from the dominant culture, which is a legitimate desire that we should all accept. Many travel to North America to make money or flee persecution and then return home; while in North America, they retain the highest possible degree of ethnic purity. While this is their right, the larger picture, the longer, more popular history of America, is one of absorption. Generally, they become a part of the assimilation process as soon as their children are born in America. The present discussion of global variety should not obscure the historical truth that previous groups of Americans, such as the Greek, Polish, and Italian ethnic communities, took centuries to adapt. It is historically dubious that ethnic groups used to integrate rapidly but now want more cultural independence. German settlements in Texas retained their German language for almost a century. Throughout America's history, there have been workplaces where only Italian or Croatian was spoken. However, these groups gradually integrate, and this is no less true today. More likely, the "melting pot" has never melted rapidly, but it has melted and continues to melt. Perhaps the most significant distinction is that ethnic groups now may strive for a different mix of integration and cultural segregation. They want to instill in their children the languages and practices of their homelands, for example, and thereby contribute to the enrichment of American culture 2526 . 
As a result, many minority cultures do not see their own art as a relativized piece of world variety to be absorbed by art students in a joyful Disneyland-style building program. African masks were sometimes forbidden to be viewed by anybody, even members of the same tribal community ${ }^{27}$, who was not a member of that secret club. They were holy artifacts whose authority had to be heeded. Is it reasonable to force these societies to "give up" their objectives for the informal, lighthearted, and amusing role of diversity education, as some authors argue?

\section{Conclusion}

As some art instructors have acknowledged, diversity encompasses a diverse range of objectives. Collins and Sandell (1992) provide four such objectives that effectively summarize what we have been discussing. These are the goals of "attack multiculturalism," in which the dominant culture is chastised for its neocolonial hegemony; "escape multiculturalism," in which the malevolent dominant culture is simply ignored in favor of more friendly cultures; "transformative multiculturalism," in which the best elements of various cultures are combined to create a kinder, gentler culture; and "repair multiculturalism," in which the dominant culture's self-image is improved .

I have attempted to define, via an examination of the work of several contributors to multicultural art education over the last decade, what I regard as the "logic" or "reason" that seems to go from the need for diversity to an anti-Western worldview. For the reasons stated above, I believe that the need for variety is clear; and this need does indeed "logically" result in the recognition of multiple aesthetic cultures as equal in worth. However, I have argued that this does not logically imply a rejection of Western aesthetics, art, or morals, as many have assumed. Above all, I have argued, this should not lead us to view multicultural art education as an effort to separate children according to their ostensibly minority cultural origins, i.e., African art for African-American students, Hispanic art for Hispanic students, and so on. Rather than that, we should continue to explore the varied cultural foundations of American culture, particularly American art, such as the African roots of American music, which are important for all of our children to understand. I've also emphasized the need of actual, "authentic" understanding of non-Western art and culture, as well as the critical role that urban museums may play in providing that basis of knowledge. I hope that in the process, we might regain a greater awareness of not just non-Western aesthetic standards, but also the richness and variety of Western aesthetics 2829293031323334291014 .

\section{References}


1. Walton, K. L. How marvelous! Toward a theory of aesthetic value. J. Aesthet. art Crit. 51, 499510 (1993).

2. Duncum, P. Visual culture: Developments, definitions, and directions for art education. Stud. art Educ. 42, 101-112 (2001).

3. Wilts, H., Garcia, B. R., Garlito, R. G., Gómez, L. S. \& Prieto, E. G. Artificial intelligence in the sorting of municipal waste as an enabler of the circular economy. Resources 10, 28 (2021).

4. Desai, D. Imaging difference: The politics of representation in multicultural art education. Stud. Art Educ. 41, 114-129 (2000).

5. Weinlich, W. Glasbeni simboli: Podobnost med simboli iz pradavnine in med risbami v zgodnjem otroštvu. Rev. za Elem. Izobr. 10, 275 (2017).

6. Desai, D. Places to go: Challenges to multicultural art education in a global economy. Stud. art Educ. 46, 293-308 (2005).

7. Adejumo, C. O. Considering multicultural art education. Art Educ. 55, 33-39 (2002).

8. Hart, L. M. Aesthetic pluralism and multicultural art education. Stud. Art Educ. 32, 145-159 (1991).

9. Chin, C. Key dimensions of a multicultural art education curriculum. Int. J. Educ. Arts 14, (2013).

10. Weinlich, W. Zur Bedeutung der Hattie-Studie für die Kunsterziehung. (2018).

11. Collins, G. \& Sandell, R. The politics of multicultural art education. Art Educ. 45, 8-13 (1992).

12. Cahan, S. \& Kocur, Z. Contemporary art and multicultural education. Art Educ. 47, 25-33 (1994).

13. Acuff, J. B. Failure to operationalize: Investing in critical multicultural art education. J. Soc. Theory Art Educ. 35, 4 (2015).

14. Weinlich, W. The Contribution of Art Education to Educational Transitions. J. Elem. Educ. 11, 251-268 (2018).

15. Blocker, H. G. Varieties of multicultural art education: Some policy issues. Handb. Res. policy art Educ. 195-208 (2004).

16. Martin, G. Teaching appreciation of cultural differences through multicultural art education. (2006). 
17. Chalmers, F. G. Designing and implementing a curriculum for multicultural art education. in Art, Culture, and Pedagogy 47-55 (Brill Sense, 2019).

18. Abdul Rahman, S. B., Maaruf, S. Z. \& Abdul Rahman, S. B. Pre-service art teachers' perception of multicultural art education and teaching students from multicultural background: An exploratory study. Asian J. Univ. Educ. 14, 89-102 (2018).

19. Stuhr, P. L. Multicultural art education and social reconstruction. Stud. art Educ. 35, 171-178 (1994).

20. Acuff, J. B. (Mis) Information highways: A critique of online resources for multicultural art education. Int. J. Educ. Through Art 10, 303-316 (2014).

21. Desai, D. Multicultural art education and the heterosexual imagination: A question of culture. Stud. Art Educ. 44, 147-161 (2003).

22. Weinlich, W. Stereotypes in Popular Feature Films and their Importance for Adolescents: How Can or Should Art Education Respond? (2020).

23. Kader, T. SchoolArts: DBAE and multicultural art education in the United States of America. Int. J. Educ. through art 1, 65-84 (2005).

24. Bode, P. Multicultural art education: Voices of art teachers and students in the postmodern era. (University of Massachusetts Amherst, 2005).

25. Chin, C. D. Critiquing commonly available multicultural art education resources. Int. J. Educ. through Art 7, 299-313 (2011).

26. Stuhr, P. L., Petrovich-Mwaniki, L. \& Wasson, R. Curriculum guidelines for the multicultural art classroom. Art Educ. 45, 16-24 (1992).

27. Kraehe, A. Multicultural art education in an era of standardized testing: Changes in knowledge and skill for art teacher certification in Texas. Stud. Art Educ. 51, 162-175 (2010). 
